\title{
Distribution of landslides reconstructed from inventory data and estimation of landslide susceptibility in Hungary
}

\author{
Edina JÓZSA ${ }^{1}$, Dénes LÓCZY², Mauro SOLDATI ${ }^{3}$, \\ LuCian DANiel DRĂGUȚª and József SZABÓ 5
}

\begin{abstract}
The complexity of landslides makes it difficult to predict the spatial distribution of landslide susceptibility and hazard. Although in most European countries the basic preconditions for the occurrence of mass movements (rocks and topography) have been mapped in detail, the triggering factors (e.g. precipitation or earthquakes) are much less predictable. A detailed nation-wide inventory for Hungary provides a unique base for landslide susceptibility mapping. As the methodology for the assessment the technique applied in the ELSUS 1000 project was selected. The micro-regions of Hungary were identified where mass movements contribute to land degradation. The paper provides a statistical evaluation of the distribution of landslides, depicts landslide susceptibility on maps and reveals the role of anthropogenic factors in the generation of mass movements. The mid-resolution elevation model (SRTM1), land cover data (CLC50) and surface geology database (Mining and Geological Survey of Hungary) allowed for the derivation of a landslide susceptibility map more detailed than before. Along with its background information the map reflects and explains the differences in landslide susceptibility among the individual hilly and mountainous regions.
\end{abstract}

Keywords: landslides, national inventory, landslide susceptibility, GIS

\section{Introduction}

Landslides are multidimensional and nonlinear dynamical natural systems variable in space and time (BRUNSDEN, D. 1999). Each phase of movement is a more or less immediate response to an external trigger which reduces the strength of the slope material (WIECZOREK, G.F. 1996). However, the drivers behind the mass movement processes, which affect the type and location of landslides, are more constant and interrelated in a complex manner (Crozier, M.J. 1986; Crozier, M.J. and Mäusbacher, R. 1999). The primary preconditions of the generation of mass move- ments on slopes are relative relief (slope), and (loose or loosened) rock masses suitable to displacement. Slope instability is influenced by the following rock mechanics parameters (GLADE, T. et al. 2005):

- rock (soil) porosity;

- water-saturated density;

- angle of internal friction;

- amount and quality of clay minerals (proportion of swelling clay minerals);

- cohesion among the particles of unconsolidated rocks.

Although this list confirms that rock quality is an important factor, mass movements cannot unequivocally be bound to the individual

\footnotetext{
${ }^{1}$ Doctoral School of Earth Sciences, University of Pécs, Pécs. E-mail: edina.j0zs4@gmail.com

${ }^{2}$ Department of Physical and Environmental Geography, Institute of Geography and Earth Sciences, University of Pécs, Pécs. E-mail: loczyd@gamma.ttk.pte.hu

${ }^{3}$ Department of Chemical and Geological Sciences, University of Modena and Reggio Emilia, Modena. E-mail: soldati@unimore.it

${ }^{4}$ Department of Geography, West University of Timişoara, Timişoara, Romania. E-mail: lucian.dragut@fulbrightmail.org ${ }^{5}$ Department of Physical Geography and Geoinformatics, Faculty of Sciences, University of Debrecen, Debrecen. E-mail: szabo.jozsef@science.unideb.hu
} 
rock types. Mass movements on slopes are widespread all over the mountain and hill regions of the Earth's surface. Some Landslides types in VARNES' classification system (VARNES, D.J. 1978; CRuden, D.M. and VARnes, D.J. 1996; Hungr, O. et al. 2014) occur under any type of climate, while other processes (e.g. displacements of frost-riven rock masses) are characteristic of the particular physico-geographical environment (Szabó, J. 1996a).

Although lubricating water promotes instability through reducing external and internal friction, it is not normally regarded an indispensable condition of mass movements. Even in arid regions special types of gravitational movements (creep) occur. Climatecontrolled movements are gelifluction in polar areas and deep slumps close to the Equator (Ollier, C.D. et al. 2007). Landslides are processes discontinuous in space and time. Research in the Alps indicates that global climate change may increase the frequency and/or magnitude of landslides but it is not expected to significantly modify the actual regional distribution of landslide hazard (Borgatti, L. and Soldati, M. 2010). Statistical and GIS methods are increasingly used to predict the place (if not the time) of landslide occurrence. The underlying assumption is that, since controlling factors do not change fundamentally over time, landslides in the future will normally occur at the same sites as before (GuzzetTi, F. et al. 1999; Cardinali, M. et al. 2002; Piacentini, D. et al. 2012; Galve, J.P. et al. 2015). Consequently, a comprehensive landslide inventory is a basic requirement of the quantification of landslide susceptibility (VAN Westen, C.J. et al. 2008).

However, it is not sufficient to simply acquire data on the location and basic attributes of the mass movement events, but GIS modelling should be incorporated in prevention and damage mitigation measures. Therefore, landslide hazard mapping is a developing field of geomorphometry with an ever-growing toolset and improving datasets. In a recent study (Sirbu, F. et al. 2018), for instance, moving window analysis was performed to identify landscape scars in an international comparative investigation. A crucial task is the scaling of land-surface variables, which is solved by applying an ever broader representation of topography through increasing window size. The modelling of landslides scarps uses the Random Forest technique (CATANI, F. et al. 2013). The research confirmed that the scale of the input predictors should be carefully established for the modelling of landslides.

Other approaches to landslide susceptibility mapping are based on a support vector machine (SVM), a machine learning algorithm, widely used in recent years (Du, W. et al. 2016; LeE, S. et al. 2017; HuAnG, Y. and ZhAO, L. 2018). The SVM method is an alternative to the analytic hierarchy process, logistic regression, artificial neural networks and random forests, which are all applied in landslide susceptibility mapping. Authors claim that the combination of SVM and other techniques may yield better performance in landslide susceptibility assessment and mapping. Naturally, the main requirement is a high-quality database which allows an accurate classification of landslides. In addition, probabilistic methods are also often applied in landslide susceptibility mapping (Fernandes, G. et al. 2016). Authors could arrive at an index which represents the probability of failure allowing for the uncertainty typical of shallow landslide processes (expressed in the factor of safety).

In the low mountains and hills of Hungary various landslides represent the most frequent types of mass movement. Landslide also cause the largest damage and land degradation (Szabó, J. 1996a). Triggering mechanisms are usually associated with the saturation of slope material (usually due to excessive rainfall events) along a distinct slip plane, where translation or rotation takes place. As a rule, relatively small areas are affected by an individual event but movements may occur repeatedly at different points in a region of similar geological setting.

Investigations of landslide hazard in potentially endangered industrial, residential, forested or agricultural areas began at the Budapest Technical University (BME), 
the Geographical Research Institute of the Hungarian Academy of Sciences (PÉcsi, M. et al. 1976) as well as other institutions, including universities. The outputs are engineering geomorphological maps at 1:10,000, 1:25,000 and 1:100,000 scales (А́DÁM, L. and PÉcsI, M. 1985). By the end of this stage the entire country had been mapped at 1:25,000 scale and the mountainous areas at 1:10,000 scale. Focal regions of the mapping project were the area of Budapest, the Lake Balaton Recreational Area and some particularly endangered towns, including the cellar systems of Eger (KLeb, B. 1978) and Pécs (SzILÁRd, J. and Schweitzer, F. 1977).

Relying on historical information revealed in inventories, the present paper undertakes to identify the terrains with high susceptibility to landslides but cannot predict the actual place and time of landslide occurrence in the delineated areas. While maps of landslide hazard are available for the entire country, an analysis of temporal variations in landslide susceptibility is increasingly important in a changing climate (GARiano, S.L. and Guzzetti, F. 2016). In addition to steep hillslopes (mostly of unconsolidated material) of the Transdanubian Mountains, the Transdanubian Hills and the North Hungarian Mountain Range, in Hungary the primarily endangered areas are high bluffs along major rivers (the Danube, Hernád/Hornad, Rába/Raab and Drava rivers) and on lakeshores (Lake Balaton and Fertö/ Neusiedlersee), where water levels and undercutting considerably contribute to landslide generation and damage.

\section{Methods}

\section{Data sources}

1. National Inventory of Mass Movements. Commissioned by the Central Geological Office $(\mathrm{KFH})$, the first stage of the national survey of mass movement took place between 1972 and 1980 (Fodor, T.-NÉ and Kleb, B. 1986; SzABó, J. 1996b). Using a standardized questionnaire designed by experts of the $\mathrm{KFH}$, a total of 1,205 landslide sites were surveyed. The systemization of the results was the task of the Hungarian State Institute of Geology (MÁFI) in 1976, with assistance of regional geological surveys, universities and research institutes. The first stage of the survey was completed in 1980, by which date databases for the counties of Hungary had been compiled. The characteristic parameters of mass movements mapped at 1:25,000 scale and with a special legend were carefully checked in the field. The survey is assessed in retrospect (Szabó, J. et al. 2008) to have met the requirements in the EU Directive INSPIRE (Information for Spatial Data in Europe) of 2007 (http://inspire.ec.europa.eu/).

Started in 1980 and coordinated by the Enterprise for Geodesy and Soil Investigation (FTV), the second stage of survey involved more detailed data collection and landslide hazard zoning. For the identification of hazard zones, a conventional colour legend was used: green, yellow and red colours showed increasing levels of hazard. The base maps were cadastral survey maps at $1: 2,000$ or 1:4,000 scales.

The launching of the third stage in 1990 had been preceded by detailed soil mechanics analyses of data from shallow boreholes. Hazard zoning was extended to the broader environs of the previously described mass movements. The survey was supplemented with maps depicting the geomorphic impacts of deep mining and, in general, all undermined surfaces (SzAвó, J. 1996b).

2. National Digital Inventory of Mass Movements. The new, electronic, version of the Inventory was created in the MÁFI and maintained by the recently set-up Hungarian Mining and Geological Office. In 2013-2014 the Inventory was supplemented with the description of 186 movements in Somogy and Baranya counties (Southwest Hungary). In addition, five landslides have been discovered by the National Expert Committee of Mitigation for Cellars and River Bluffs in recent decades. The electronic system allows queries at settlement level. Experimentally, the details of damage can be queried for the 
individual events in Fejér County. In accordance with legislation on natural disasters (Act 128/2011 on disaster prevention, Kluwer Wolters Kft. 2017), special attention is paid to cellar collapses, topples of river bluffs and landslides. The updated digital version of the inventory is also available as KMZ file or as WFS/WMS layer to explore in Google Earth or GIS software.

\section{Method for the regional assessment of landslide susceptibility in Hungary}

When preparing the landslide susceptibility map of Hungary, the methodology of the ELSUS 1000 (European Landslide Susceptibility Map) project (GüNTHER, A. et al. 2014a, European Landslide Expert Group) was followed. The Pan-European ELSUS1000 map of 1:100,000 scale is based on a weighted multi-parameter regional assessment. Since the database (the National Digital Inventory of Mass Movements) allows representation at a higher resolution, a $30 \times 30 \mathrm{~m}$ grid was created to show the spatial distribution of landslide susceptibility. The targeted level of detail is adjusted to the corrected SRTM1 Digital Surface Model (Józsa, E. and FÁBı́́n, Sz.Á. 2016) used for the assessment.

The first step in the mapping procedure was the compilation of input maps, their classification and transformation to a grid map of uniform resolution. Following the approach of the European Landslide Expert Group (GüNTHER, A. et al. 2014b) slope inclination, the character of geological formations exposed on the surface and land cover were considered the fundamental criteria for classification. It was assumed that these are the factors on which the representation of the spatial pattern of mass movements can be founded. The temporal analysis of sliding was not aimed at, the date of movement was not included, and dynamic triggers, such as rainfall events and seismic activity, were also left out from the investigation.

Slope inclination was derived from the corrected SRTM1 model. Information of surface rocks was obtained from the covered geological database at 1:100,000 scale (GYaLOG, L. 2005; Gyalog, L. and Síkhegyi, F. 2005), while for land cover the national CORINE database at 1:50,000 scale was employed (BüTTNER, Gr. et al. 2005). The CLC50 is a post-processed version of 1998-2000 data by the Hungarian Institute of Geodesy, Cartography and Remote Sensing (FÖMI). The time of data acquisition and the resolution well matched the SRTM1 model. In accordance with the methodology described in the above mentioned paper (Günther, A. et al. 2014a), slope inclination was referred into 8 classes, geological formations into 13 and land cover into 7 classes.

The expert group defined the relative weights of the three input parameters by means of the Analytic Hierarchy Process (AHP - SAATY, T.L. 2012). In the application of the method for Hungary the same weights were used: slope inclination had the largest weight (0.64), followed by surface rocks (0.26), while land cover received a remarkably lower weight (0.1) (GüNTHER, A. et al. $2014 b$ ). The areal extension rate (area of class / total area) and rate of mass movements (pixels of landslides in class / total landslide pixels) was rendered to the particular classes of the input parameters. An indicator for the frequency of occurrence of mass movement events normalized on the basis of areal extension of the class was also calculated (rate of mass movements / areal extension rate). The frequency ratio provides the base for weighting and for the detection of overrepresented categories.

During the implementation of the method only the calculated 'built-in' class weight required correction, because the high event frequency probably resulted from data recording and generalized boundaries of CORINE data. Other weight factors were accepted for generating the landslide susceptibility values. The method aimed to select classes that are representative of the geographical characteristics over the Pannonian Basin and have a sufficient number of mass movement events to use in the modelling. Detailed reliability analysis regarding the method of the ELSUS 1000 map revealed that the main limitation to 
the identification of landslide susceptibility was the incompleteness of mass movement dataset (GüNTHER, A. et al. 2014a,b). As substantially more $(1,726)$ events were available for interpretation than in the Pan-European survey, the reliability of the calculated hazard map is considered appropriate to draw spatial conclusions. Moreover, the application of this methodology to produce a landslide susceptibility map for the territory of Hungary is a step towards the aim of the project, which is the harmonization of different landslide zoning approaches in Europe.

\section{Results and discussion}

The classification of data according to basic land-surface variables like slope inclination, surface materials and land cover provided a differentiated picture of the circumstances under which landslides developed (Figure 1).
The calculated frequency ratios show that the most endangered areas have slope inclinations between $11^{\circ}$ and $15^{\circ}$, predominantly underlain by sandstones, flysch and molasse sediments, where land cover shows no or little vegetation cover. It has to be taken into consideration that the classes with small areal extension can exhibit high frequency values. A more direct analysis of the spatial characteristics of mass movement events is also performed on the basis of the inventory data and presented later in the study.

Based on the above outlined method, the landslide susceptibility map of Hungary was prepared (Figure 2). The degree of susceptibility in percentage resulted from the weighted linear summation of the input parameters and is intended to reflect the extension, proportion and frequency of mass movements occurred. It is a characteristic feature of the procedure and input elevation dataset that lowland settlements of larger extension present higher values,

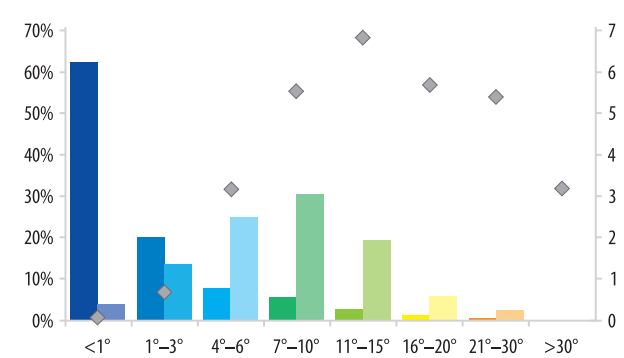

$\boldsymbol{A}$

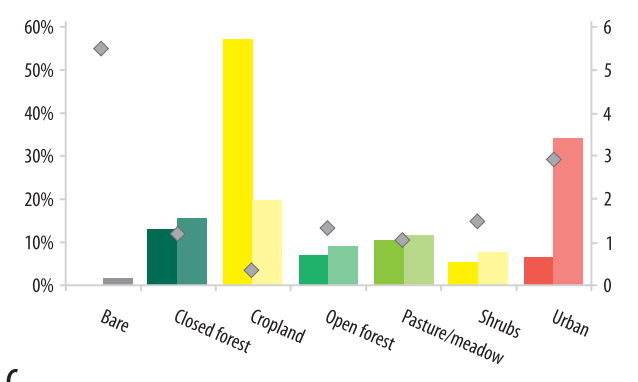

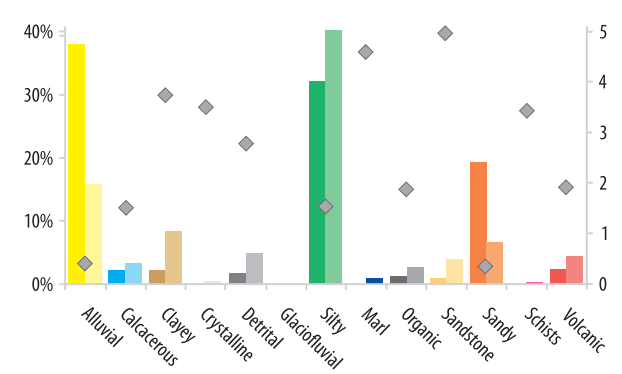

B

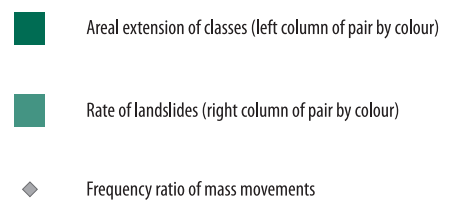

Fig. 1. Percentages of classified slope inclination (A), surface geology (B), and land cover (C) showing areal extension of classes, rate of landslides and frequency ratio of mass movements 


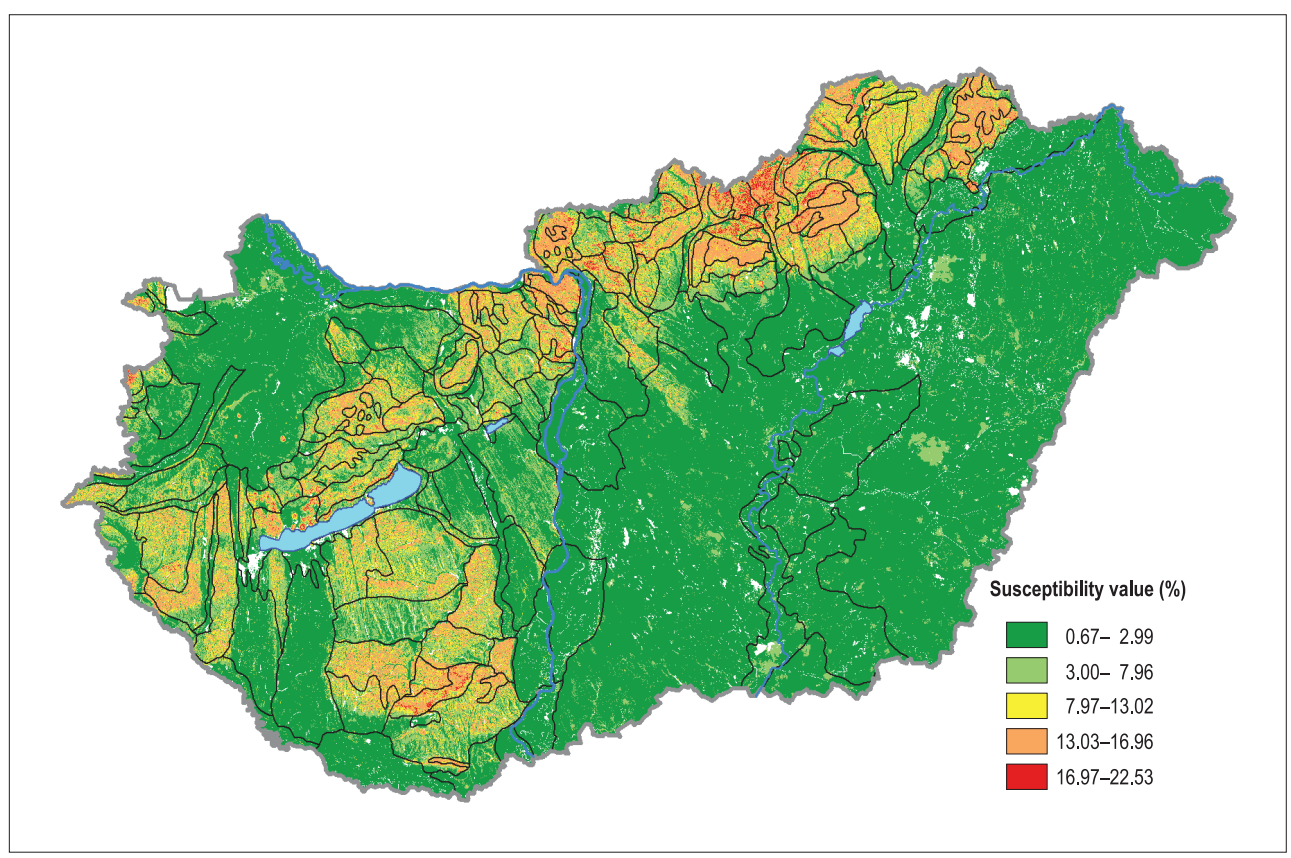

Fig. 2. Percentage landslide susceptibility map of Hungary showing the boundaries of micro-regions affected by mass movements (boundaries after the National Atlas of Hungary 2018, 126-127.)

which is a deficit of the DTM data and could not be eliminated by the reduced weight $(0.1)$ of the land cover input parameter. For categorization the Jenks Natural Breaks approach of the ArcGIS was employed and adjusted manually based on the histogram of the values to better distinguish between lower categories as well.

The hilly and mountainous regions of silty (loess), clayey, volcanic or sandstone geology classes can be well distinguished on the map. The classification of the slope inclination categories also made it possible to exclude valley bottoms. In accordance with previous surveys, the high bluffs along the Danube, Hernád/Hornad and Drava rivers show higher susceptibility. The highest absolute and mean susceptibility values occur in the micro-regions of the North Hungarian Basins, the Mátra and Bükk mountains, the Cserhát region, the Central Zemplén region, the Danube Bend and Börzsöny Mountains as well as the Mecsek Mountains surrounded by the Tolna-Baranya Hills and the Zala Hills.
For the implementation of prevention and mitigation efforts, it is expedient to have information on the number of mass movements in the administrative units of the country. The distribution of recorded events by counties shows that in five counties of the Great Hungarian Plain (Békés, Csongrád, HajdúBihar, Jász-Nagykun-Szolnok and SzabolcsSzatmár-Bereg) practically no events occurred except from movements of the Tisza bank or embankment of major roads. On the other hand, in six counties with mountainous and hilly relief (Baranya, Fejér, Borsod-AbaújZemplén, Heves, Komárom-Esztergom and Nógrád) movements were documented on more than 100 occasions (Figure 3). In Fejér County the majority of the events are concentrated along the high bluff of the Danube.

Investigating the movements by settlements, it was found that there are 75 settlements (including the districts of Budapest) where mass movement phenomena were observed on at least five occasions (Figure 4). The frequency 


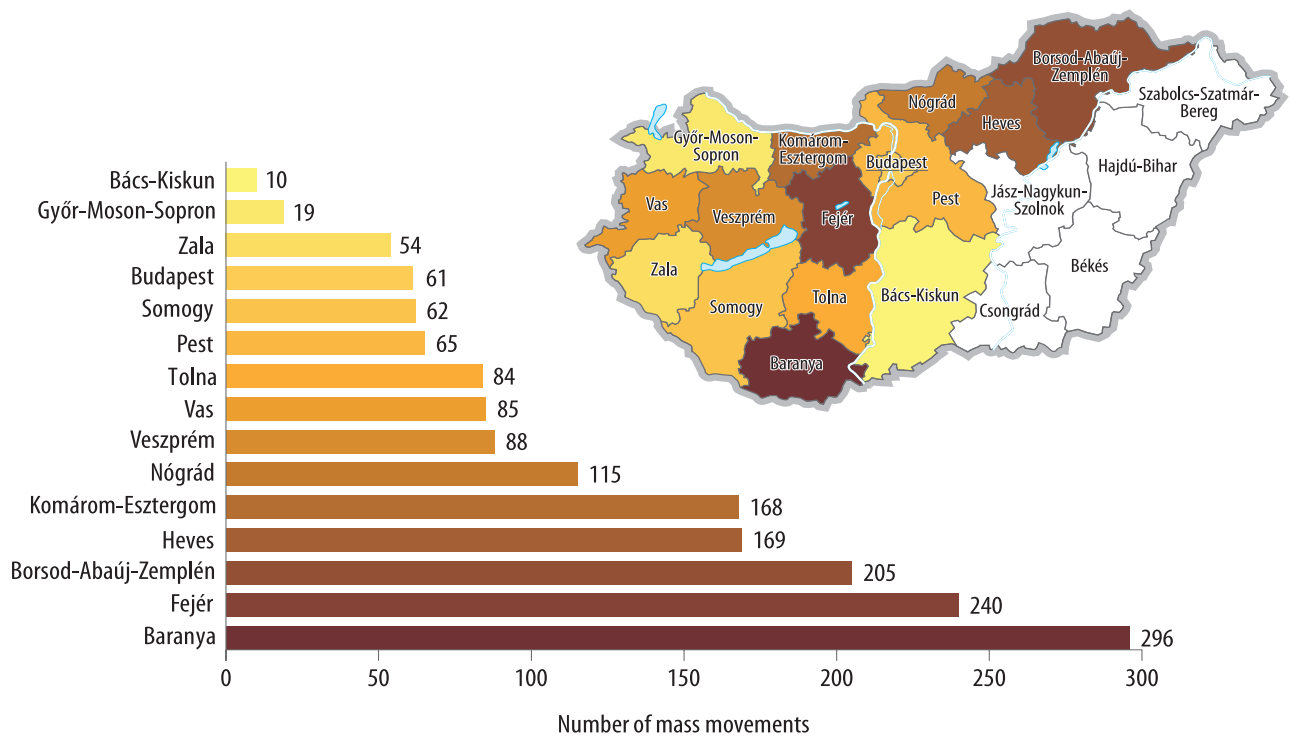

Fig. 3. Distribution of mass movements by counties

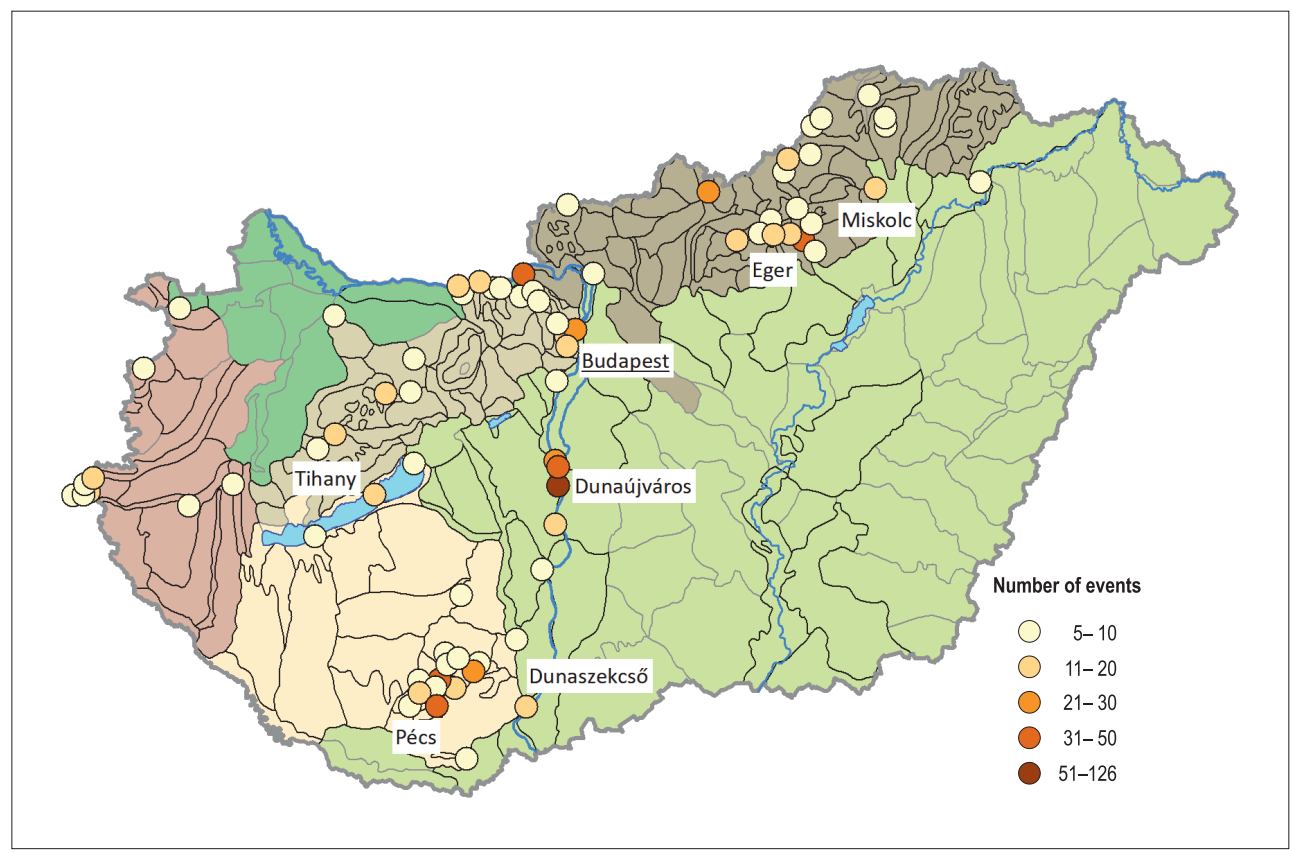

Fig. 4. Settlements with at least 5 recorded mass movement events on the map of physical regions of Hungary 
distribution of movements is also illustrated by Table 1, which shows settlements where 10 or more events were recorded.

From the viewpoint of physical geography, the distribution of landslides by physical microregions is of greater significance (Szabó, J. 1996a,b; Szabó, J. et al. 2008).
Figures 5 and 6 show the spatial distribution of the landslide events in these micro-regions and reveal hot spots of mass movements. Maximum number of events was recorded in the Central Mezőföld, along the right bank of the Danube, South of Budapest ( $>200$ occasions). Significant number of mass move-

Table 1. Settlements of Hungary most often ( $\geq 10$ times) affected by mass movements

\begin{tabular}{c|l}
\hline $\begin{array}{c}\text { Number of } \\
\text { events }\end{array}$ & \\
\hline 126 & Dunaújváros \\
50 & Rácalmás \\
38 & Eger, Pécs \\
37 & Esztergom \\
31 & Komló \\
26 & Budapest III., Kulcs \\
24 & Salgótarján \\
22 & Mecseknádasd \\
18 & Miskolc \\
17 & Neszmély \\
15 & Parádsasvár, Szentgotthárd \\
13 & Apátistvánfalva, Egerbakta, Tihany \\
12 & Budapest II., Lábatlan, Ózd \\
11 & Budapest XII., Dudar, Dunaföldvár, Dunaszekcső, Hosszúhetény, Orfü, Sirok, Városlőd \\
10 & Balatonkenese, Kesztölc, Szekszárd, Vác \\
\hline
\end{tabular}

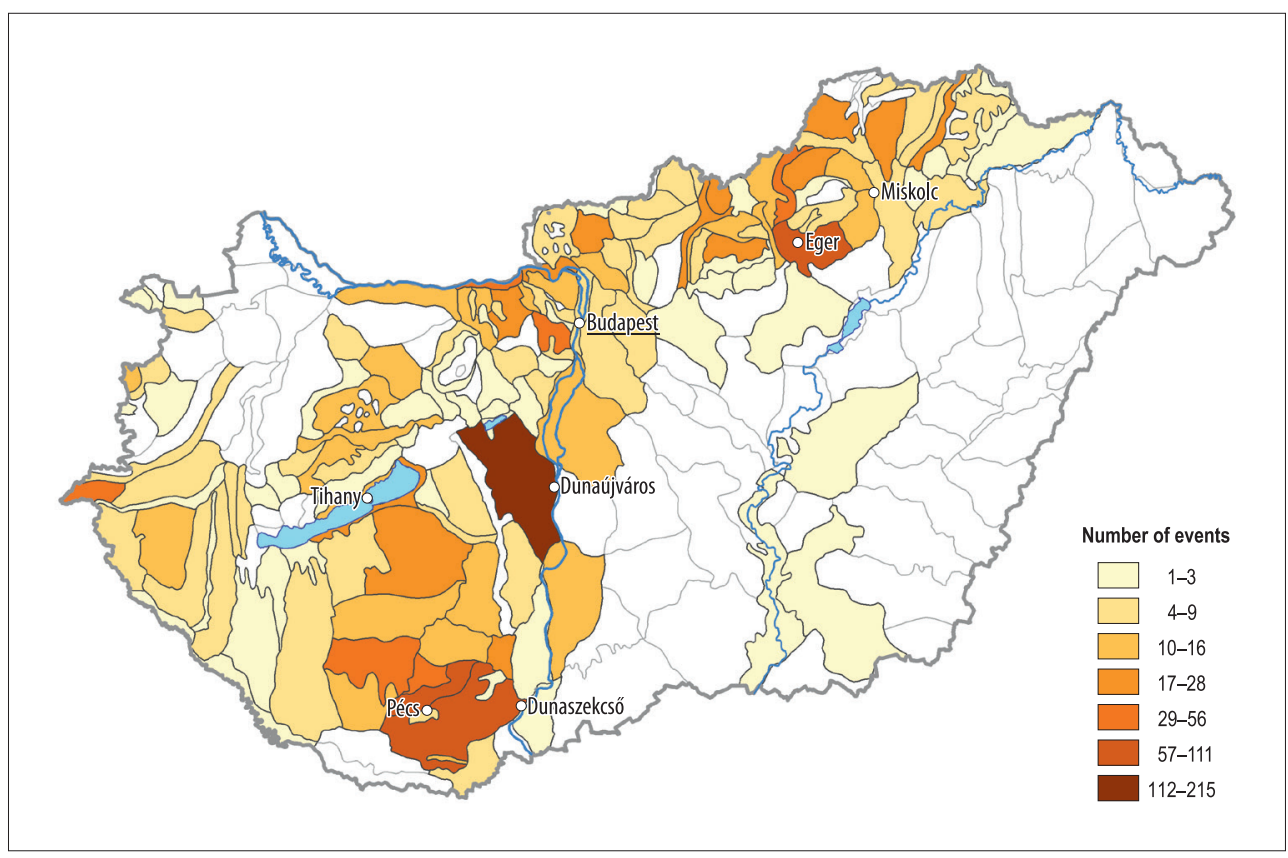

Fig. 5. Number of mass movements by physical micro-regions 


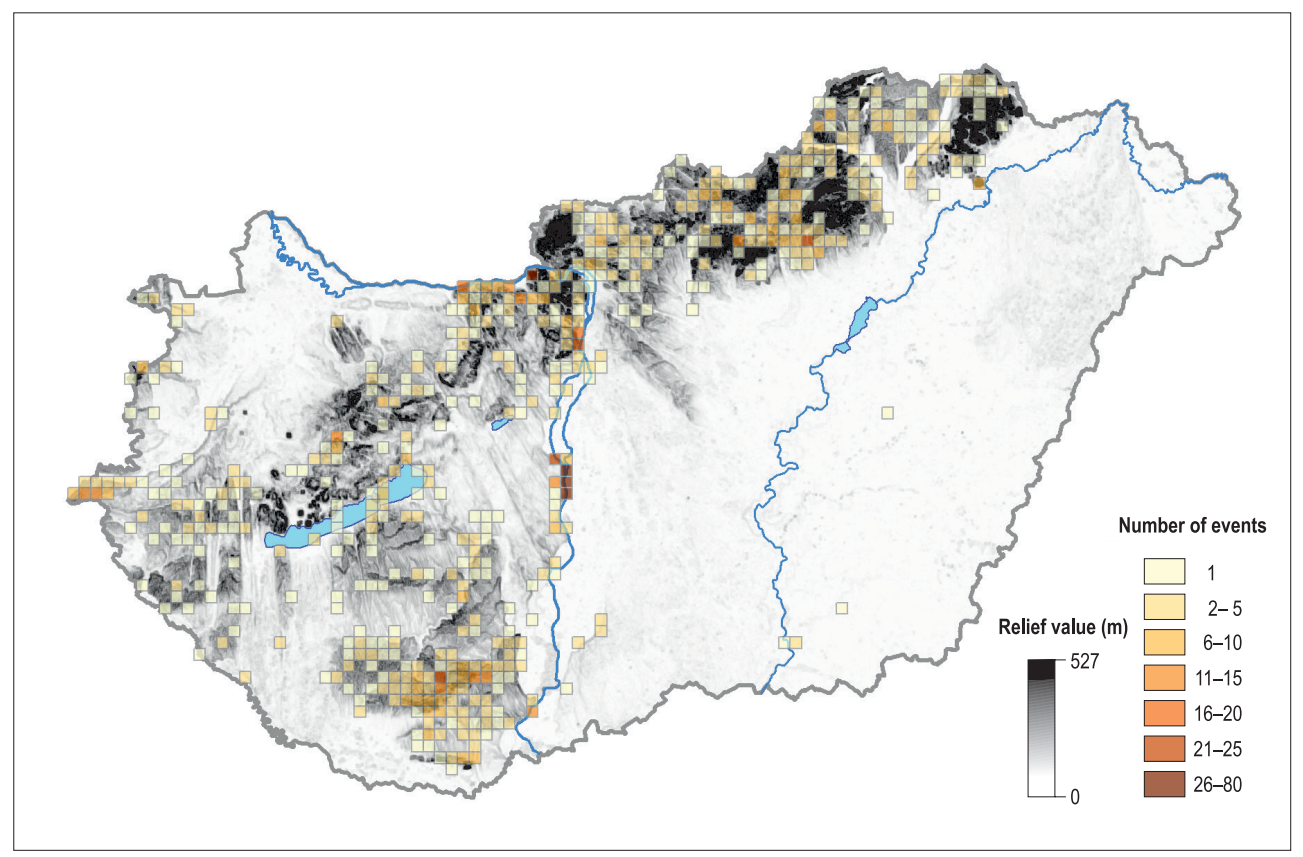

Fig. 6. Density of mass movement events (number per $25 \mathrm{~km}^{2}$ ) overlaid on the relative relief map $\left(\mathrm{m} / \mathrm{km}^{2}\right)$ of Hungary

ments occurred in foothill areas: in Southwest Hungary in the South Baranya Hills (111) and the Baranya Hegyhát (53), in North Hungary in the Eger Bükkalja (68) and in West Hungary in the Vas Hegyhát (56). Similarly, abundant are landslides in some basins of low mountains, such as the Ózd-Egercsehi (34) and the Nógrád basins (21) in North Hungary and in the Veszprém-Devecser Graben (13) in Transdanubia. Among the valleys of major rivers (which are regarded independent physical microregions), the Danube (the section between Dunaalmás and Tát, 45), the Zagyva (20), the Tarna (12), the Rába (9) and the Sajó valleys (7) stand out.

The highest densities are observed in Transdanubia, in the areas of the Vas Hegyhát, the Buda Hills, along the right bank of the Danube and the Baranya Hegyhát (Figure 6).

The interactions between landslides and topographic parameters were studied on the basis of the corrected SRTM1 DSM of $\sim 30 \mathrm{~m}$ horizontal resolution. Classifying events ac- cording to elevation above sea level, an outstanding influence of hill regions is found: 1,511 events ( $87 \%$ of all) falls within the elevation interval between 100 and $300 \mathrm{~m}$ (Figure 7). The slope angles of movements are rather low: they are less than 12 per cent for half of the events and only 197 were developed on steep (>25\%) surfaces (Figure 8, A).

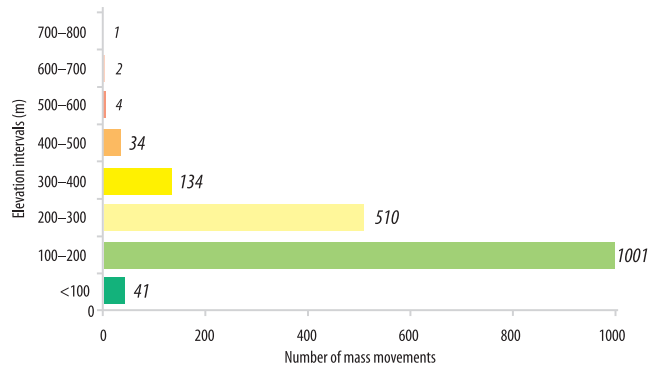

Fig. 7. Distribution of mass movements by elevation intervals above sea level 


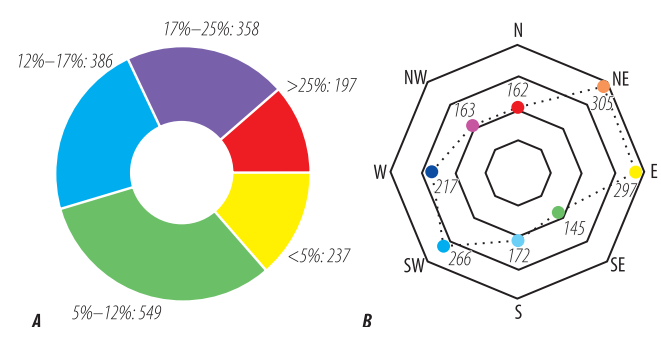

Fig. 8. Distribution of movements by the slope inclination categories used in agriculture (A), and slope exposure (B)

The DEM also supplies data on the distribution of movements according to slope exposure (Józsa, E. et al. 2014) (Figure 8, B). The figure shows a predominance of eastern exposure, which can be explained with the abundant number of landslides along the Danube between Kulcs and Dunaszekcső. Also, an increase of events can be observed in NE and SW directions, which coincides with the general NW-SE orientation of valleys over Transdanubia. Other cardinal directions are fairly equally represented.

The movements fall into various types. According to the categories applied by the MÁFI the following occur most often: rotational slides (426 sites), sliced landslides (327), layered slides (278), bank collapses (123), creep phenomena (120). Separately from bank collapses there were 39 reported events of loess collapses. In addition, regional land subsidence (46 cases) and instabilities of embankments (>100 cases) have also been recorded. Other instabilities of anthropogenic origin affect undermined areas, cellar systems and spoil heaps.

As far as dynamics is concerned, the return interval (periodicity) of movements is an important factor. In the nation-wide inventory the temporal aspect is characterized by attributes like fossil, ongoing, occasional, periodic and one-time. (In case of 305 events such information was not included in the dataset, these are mainly movements along the high bluff of the Danube). Altogether 623 ongoing, 452 occasional, 253 one-time, 79 periodic and 14 fossil (non-active) movements have been recorded.
The inventory data also provide some information on the triggering mechanism responsible for the mass movement. The most widespread among the triggers is oversaturation of slope material (in $>600$ cases) as a result of seepage of water in the sediment mass (mentioned separately for $\sim 130$ events), complex natural processes ( 140) and complex anthropogenic interventions ( 130) had large impacts as well (Figure 9).

As far as the temporal pattern of mass movements is concerned (see e.g. Crozier, M.J. and Mäusbacher, R. 1999), it is claimed that weather-related events (first of all, extreme rainfall events) are major contributors. This observation is underlined by the fact that in Hungary the number of movements was extraordinarily high in 2010, which was by far the most humid year since the beginning of regular meteorological observations (Table 2). (Naturally, floods were also common in 2010. Although 2011 was the driest year ever in Hungary, frequent movements happened as an aftermath of wet conditions in the previous year.)

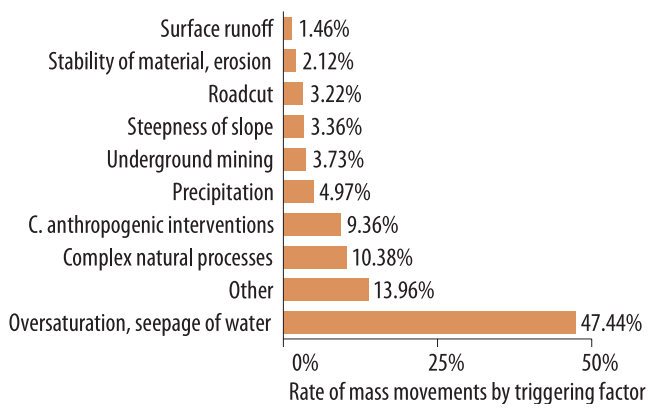

Fig. 9. Known triggering factors (excluding no data)

Table 2. Recently reported mass movements in Hungary

\begin{tabular}{c|c|c|c}
\hline \multirow{2}{*}{ Year } & Reported & Total & Number of \\
\cline { 2 - 3 } & \multicolumn{2}{|c|}{ vis maior cases } & landslides \\
\hline 2005 & 100 & 118 & 12 \\
2006 & 111 & 134 & 19 \\
2007 & 63 & 85 & 7 \\
2008 & 75 & 106 & 5 \\
2009 & 101 & 121 & 4 \\
2010 & 515 & 640 & 128 \\
2011 & 90 & 116 & 35 \\
\hline
\end{tabular}

Source: Oszvald, T. 2011. 


\section{Conclusions}

The engineering geomorphological investigations carried out over several decades allow to draft a relatively complete picture on the regional distribution of landslides in Hungary and to identify the main drivers of surface instability in the individual regions. The interpretation of data using a GIS provides vital information for engineering geomorphology and disaster prevention.

Comparing our results with the ELSUS 1000 v1 map (Günther, A. et al. 2014a), mountains do not necessarily represent the highest class of susceptibility (for instance, in the case of the Bükk and Mátra Mountains) as this was decided a priori by GüNTHER, A. et al. (2014a). The conclusions drawn from the inventory underpin practical interventions with the purpose of mitigation of damage associated with natural hazards.

1. Transdanubian Hills.

Susceptibility to sliding is primarily due to the lithological setting of the hill region: Upper Miocene-Pliocene sands and clays, Pleistocene fluvial sands and loess, Holocene alluvia, blown sand. Landslides are mostly associated with Pannonian (Upper MiocenePliocene) clays and in soils of high clay content, often along highly asymmetric stream and river sections.

2. Intramontane basins in the Transdanubian Mountains.

The basins are filled up with Miocene clays, sands, marls and Pleistocene loess in variable thicknesses. The primary causes of landslides are great contrasts in geological build-up and heavily dissected relief. Movements are typical of the dissected Upper Pliocene pediments (for instance, in the Gerecse at Esztergom, at Ajka in the Bakony and at Komló in the Mecsek Mountains).

3. Danubian terraces and high bluffs.

As a consequence of minute dissection of the surface, high relief, there are intensive movements, also active at present. Considering surface geology, distinct rock types can be identified. In the Danube Bend Mountains Tertiary clays, sands, marls and gravelly deposits; Pleistocene terrace gravels, various types of loess, travertine and locally Mesozoic sediments are affected. In the Gerecse, movements occur in the sides of valleys cut down to the Miocene clays into the loess-paleosol sequence of $20 \mathrm{~m}$ thickness. Near Esztergom fossil (Late Pleistocene and Early Holocene) slumps have been described from Oligocene clays, sands and Miocene andesite. Along the steep Danubian high bluff South of Budapest paleosols and loess overlie clays and sands. Before regulation regular undercutting by the Danube removed landslide tongues and generated repeated rotational landslides and topples.

4. Intramontane and foreland basins in the North Hungarian Mountain Range.

The basin sediments susceptible to sliding are Oligocene and Miocene clays and sands. Neotectonic tilting contributes to landslide generation. Upper Pliocene pediments were uplifted and dissected, creating high relief, where fossil and recent slumps equally occur. In the most through studied region, the Cserehát Hills (Szabó, J. 1985) and in the Tokaj Mountains the slip planes developed on the Pannonian (Miocene-Pliocene) clays. In the intermontane basins (Nógrád, Borsod and Salgótarján basins) the contributing factors are similar to those in the mountain foreland. In the mountains of volcanic origin sliding took place on unconsolidated Miocene sediments or heavily weathered tuff layers below the volcanic sequence.

5. Land subsidence of anthropogenic origin above deep mines and spoil heap slips.

Further mass movements occurred in the environs of abandoned deep coal mines (Komló, Salgótarján, Sárisáp, Oroszlány, Ajka, Dudar and Tatabánya). Land subsidence extend over large areas, up to $3 \mathrm{~km}$ in diameter (JuHÁsz, Á. 1976). Vulnerability and damage to structures is considerable in the undermined and built-up areas of Komló, Tatabánya and Dorog towns.

In other mining areas of Hungary diverse landform assemblages have evolved. In the Borsod Coal-mining District numerous spoil heaps were accumulated, where the bound- 
ary between in situ and upheaped material is a potential slip plane (SüTő, L. et al. 2016). The conical spoil heaps are 20-50 m high. On their steep slopes mantle slides developed with extensive tongues.

Spoil heaps differ substantially from other landslide-prone surfaces in their physical and chemical processes. Spontaneous combustion promotes compaction and disintegration. The frost cracks dissect blocks and a laminar structure in the heap leads to failure scarps. The measurement carried out on failure walls (Süтó, L. et al. 2010) indicate that the attenuation of movements strongly depends on weather conditions, the intensity of spring snowmelt and extraordinary rainfall events. The rate of movements amounts to ca. $0.5 \mathrm{~m}$ per month.

Further research could be based on the ELSUS 1000 V2, released recently with updated methodology. The improved resolution and richness of national datasets definitely facilitate the derivation of landslide susceptibility maps and the ELSUS method is a promising tool to produce comparable continent-wide output maps. The nation-wide inventory is a valuable dataset maintained by the GeoBank of the Hungarian Mining and Geological Service (MBFSZ) allowing to regularly revisit the assessment and reveal possible temporal changes in the spatial distribution of mass movements, and to explore changes in their triggering factors.

\section{REFERENCES}

ÁDÁM, L. and PéCSI, M. (eds.) 1985. Mérnök-geomorfológiai térképezés (Engineering geomorphological mapping). Budapest, Geographical Research Institute, Hungarian Academy of Sciences.

Borgatti, L. and Soldati, M. 2010. Landslides and climate change. In Geomorphological Hazards and Disaster Prevention. Eds.: Alcántara-Ayala, I. and Goudie, A.S., Cambridge, Cambridge University Press. 87-95.

BrunsDen, D. 1999. Some geomorphological considerations for the future development of landslide models. Geomorphology 30. (1-2): 13-24.

Büttner, Gy., Maucha, G., Bíró, M., Kosztra, M., Pataki, R. and Petrik, O. 2005. National land cover data base at scale 1:50,000 in Hungary. Budapest, Institute of Geodesy, Cartography and Remote Sensing (FÖMI). Available at http://fish.fomi.hu/ letoltes/nyilvanos/corine/CLC50_article.pdf

Cardinali, M., Reichenbach, P., Guzzetti, F., Ardizzone, F., Antonini, G., Galli, M., Cacciano, M., Castellani, M. and Salvati, P. 2002. A geomorphological approach to the estimation of landslide hazards and risks in Umbria, Central Italy. Natural Hazards and Earth System Science 2. (1-2): 57-72.

Catani, F., Lagomarsino, D., Segoni, S. and Tofani, V. 2013. Landslide susceptibility estimation by random forests technique: sensitivity and scaling issues. Natural Hazards and Earth System Science 13. (11): 2815-2831.

Crozier, M.J. 1986. Landslides: Causes, Consequences, and Environment. London, Croom Helm.

Crozier, M.J. and Mäusbacher, R. (eds.) 1999. Frequency and Magnitude of Geomorphological Processes. Zeitschrift für Geomorphologie, Supplementband 115.

Cruden, D.M. and Varnes, D.J. 1996. Landslide Types and Processes. In Landslides: Investigation and Mitigation. Eds.: Turner, A.K. and Schuster, R.L., Special Report 247. Transportation Research Board, Washington, D.C., National Academy Press. 36-75. Du, W., Wu, Y., Liu, J., Zhang, J. and Zhu, L. 2016. Landslide susceptibility mapping using support vector machine model. Electronic Journal of Geotechnical Engineering 21. (20): 7069-7084.

Fernandes, G., Martínez, H.E., Moreira de Souza, N., Pacheco de Assis, A. and Rodriguez Rebolledo, J.F. 2016. Landslide susceptibility mapping using GIS and probabilistic methods. Electronic Journal of Geotechnical Engineering 21. (25): 10281-10298.

Fodor, T.-NÉ and KLEB, B. 1986. Magyarország mérnökgeológiai áttekintése (An engineering geological overview of Hungary). Budapest, Múszaki Könyvkiadó

Galve, J.P., Cevvasco, A., Brandolini, P. and Soldati, M. 2015. Assessment of shallow landslide risk mitigation measures based on land use planning through probabilistic modelling. Landslides 12. (1): 101-114.

Gariano, S.L. and Guzzetti, F. 2016. Landslides in a changing climate. Earth-Science Reviews 162. $227-252$.

Glade, T., Anderson, M. and Crozier, M.J. (eds.) 2005. Landslide Hazard and Risk. Chichester, John Wiley and Sons. Doi: 10.1002/9780470012659

Günther, A., Hervás, J., Van den Eeckhaut, M., Malet, J.-P. and Reichenbach, P. 2014a. Synoptic Pan-European landslide susceptibility assessment: The ELSUS $1000 \mathrm{v} 1 \mathrm{map}$. In Landslide Science for a Safer Geoenvironment Vol. 1. Eds.: Sassa, K., CANUTI, P. and YIN, Y. Cham, Switzerland, Springer, 117-122.

Günther, A., Van den Eeckhaut, M., Malet, J.-P., Reichenbach, P. and Hervás, J. 2014b. Climate- 
physiographically differentiated Pan-European landslide susceptibility assessment using spatial multi-criteria evaluation and transnational landslide information. Geomorphology 224. 69-85. Doi: 10.1016/j.geomorph.2014.07.011

Guzzetti, F., Carrara, A., Cardinali, M. and ReICHENBACH, P. 1999. Landslide hazard evaluation: a review of current techniques and their application in a multi-scale study, Central Italy. Geomorphology 31. (1): 181-216.

Gyalog, L. (ed.) 2005. Magyarázó Magyarország fedett földtani térképéhez, 1:100 000 (Memoir to the covered geological map of Hungary, 1:100,000). Budapest, Hungarian State Institute of Geology (MÁFI).

Gyalog, L. and Síkhegyi, F. (ser. eds.) 2005. Magyarország földtani térképe, 1:100 000 (Geological map of Hungary, 1:100,000). Budapest, Hungarian Geological and Geophysical Institute. Available at https://map.mfgi.hu/fdt100/

HuANG, Y. and ZHAO, L. 2018. Review on landslide susceptibility mapping using support vector machines. Catena 165. 520-529. Doi: 10.1016/j.catena.2018.03.003

Hungr, O., Leroueil, S. and Picarelli, L. 2014. The Varnes classification of landslide types, an update. Landslides 11. (2): 167-194. Doi: 10.1007/s10346-0130436-y

JózsA, E. and FÁBIÁn, Sz.Á. 2016. Az SRTM-1 modell korrigálása Magyarországra (Correcting the SRTM-1 model for Hungary). Természetföldrajzi Közlemények a PTE Földrajzi Intézetéből (Pécs) 2016. 1. 13-22. Doi: 10.17799/2016.1.13

Józsa, E., FÁbián, Sz.Á. and Kovács, M. 2014. An evaluation of EU-DEM in comparison with ASTER GDEM, SRTM and contour-based DEMs over the Eastern Mecsek Mountains. Hungarian Geographical Bulletin 63. (4): 401-423. Doi: 10.15201/hungeobull.63.4.3

JuHÁsz, Á. 1976. Az antropogén hatások vizsgálata és térképezése ipari-bányászati területeinken (Investigation and mapping of anthropogenic effects in the industrial-mining areas of Hungary). Földrajzi Értesíto" / Hungarian Geographical Bulletin 25. (2-4): 249-253.

KLEB, B. 1978. Eger múltja a jelenben (Eger's past in the present). Eger, Eger Town Council.

Kluwer Wolters Kft. 2017. 2011. évi CXXVIII. törvény a katasztrófavédelemről és a hozzá kapcsolódó egyes törvények módosításáról (The act 128/2011 on disaster prevention and the modification of related legislation). Available at http://net.jogtar.hu/jr/gen/ hjegy_doc.cgi?docid=A1100128.TV

LeE, S., Hong, S.-M. and Jung, H.-S. 2017. A support vector machine for landslide susceptibility mapping in Gangwon province, Korea. Sustainability 9. 48-58. Doi:10.3390/su9010048

Ollier, C.D., Calcaterra, D. and Parise, M. 2007. Studies in weathering and slope movements - an introduction. Geomorphology 87. 101-103.
Oszvald, T. 2011. Geologic hazards, experiences of catastrophes. Budapest, Geographical Research Institute, Hungarian Academy of Sciences.

Pécsi, M., Juhász, Á. and Schweitzer, F. 1976. A magyarországi felszínmozgásos területek térképezése (Mapping mass movements in Hungary). Földrajzi Értesitö / Hungarian Geographical Bulletin 25. (2-4): 223-238.

Piacentini, D., Troiani, F., Soldati, M., Notarnicola, C., Savelli, D., Schneiderbauer, S. and Strada, C. 2012. Statistical analysis for assessing shallow-landslide susceptibility in South Tyrol (South-eastern Alps, Italy). Geomorphology 151. 196-206.

SAAtY, T.L. 2012. Decision Making for Leaders: The Analytic Hierarchy Process for Decisions in a Complex World. Third revised edition. Pittsburgh, PA., RWS Publications.

Sirbu, F., Drăguț, L.D., Oguchi, T., Hayakawa, Y. and Micu, M. 2018. Sensitivity of land-surface variables to scale in identifying landslide scarps. Geomorphometry 2018. $5^{\text {th }}$ International Conference of ISG, Boulder CO., 13-17. August, 2018. 221-224.

Süтô, L. 2010. Mining: Extraction of fossil fuels. In Anthropogenic Geomorphology: A Guide to Man-Made Landforms. Eds.: Szabó, J., DÁvid, L. and Lóczy, D., Dordrecht, The Netherlands, Springer International Publishing, 131-154.

Sütő, L., Gombos, B., Szögyéni, I. and Adorján, B. 2016. Meddőhányók és felszínsüllyedések a KeletBorsodi-szénmedence északi részén (Spoil heaps and land subsidences in the northern part of the Eastern Borsod Coal Basin). In VIII. Magyar Földrajzi Konferencia, Eds.: РАјтóк-TARI, I. and Tóth, A., Eger, Eszterházy Károly Egyetem, 210-219.

Szabó, J. 1985. Csuszamlásvizsgálatok a Csereháton (Investigations of landslides in the Cserehát Hills). Földrajzi Értesítő / Hungarian Geographical Bulletin 34. (3-4): 409-429.

Szabó, J. 1996a. Csuszamlásos folyamatok szerepe a magyarországi tájak geomorfológiai fejlődésében (The role of landslide processes in the geomorphic evolution of Hungarian regions). Debrecen, Kossuth Egyetemi Kiadó.

Szabó, J. 1996b. Results and problems of cadastral survey of slides in Hungary. In Landslides. Eds.: Chacón, J., Irigaray, C. and Fernández del Castillo, T., Rotterdam, A.A. Balkema, 63-78.

Szabó, J., Lóki, J., Tóth, Cs. and Szabó, G. 2008. Natural hazards in Hungary. In Dimensions and Trends in Hungarian Geography. Eds.: Kertész, Á. and KovÁcs, Z., Budapest, Geographical Research Institute, Hungarian Academy of Sciences, 55-68.

Szilárd, J. and Schweitzer, F. 1977. Pécs belváros 1:5000-es méretarányú mérnökgeomorfológiai térképlap és magyarázója (Engineering geomorphological map and memoir of central Pécs at 1:5,000 scale). Manuscript. Budapest, Geographical Research Institute, Hungarian Academy of Sciences. 
Van Westen, C.J., Castellanos, E. and Kuriakose, S.L. 2008. Spatial data for landslide susceptibility, hazard, and vulnerability assessment: an overview. Engineering Geology 102. (3-4): 112-131.

VARNES, D.J. 1978. Slope movement types and processes. In Landslides, analysis and control. Eds.: Schuster, R.L. and KRIzeK, R.J., Special report 176. Transportation Research Board. Washington, D.C., National Academy of Sciences Press, 11-33.
WieczoreK, G.F. 1996. Landslides triggering mechanisms. In Landslides: Investigation and Mitigation. Eds.: Turner, A.K. and Schuster, R.L., Special Report 247. Transportation Research Board, Washington, D.C., National Academy of Sciences Press, 76-90. 